\title{
PARENTS AND STUDENTS' RESPONSE TO DISTANCE LEARNING (GOOGLE CLASSROOM)
}

\author{
Novida Renoningtyas ${ }^{1 *}$ and Erna Risfaula Kusumawati ${ }^{2}$ \\ Post Graduate Study Program of Islamic Primary School, \\ Institut Agama Islam Negeri Salatiga, Indonesia \\ *Email : novidanovie03@gmail.com \\ Website: \\ https://jurnal.uinantasari.ac.id/index.php/adzka \\ Received: 25 October 2020; Accepted: 24 June 2021; Published: 30 June 2021 \\ DOI: 10.18952 /aladzkapgmi.v11i1.4174
}

\begin{abstract}
This study aims to determine the response of parents and primary students to distance learning based on google classroom during the Covid-19 pandemic. The method used in this study is a qualitative method with data collection in the form of interviews, documentation, and observation. The results showed that both students and their parents objected to using google classroom as a learning media for distance learning activities. According to their explanation, the use of Google Classroom requires strong network access to open or send assignments, besides that data packets also run out quickly due to the use of this distance learning application. For students and parents who have difficulty, an alternative to overcome this is to send assignments via WhatsApp to the teacher concerned.
\end{abstract}

Keywords: distance learning; google classroom; covid-19

\section{INTRODUCTION}

Coronavirus disease 2019, often refer to as Covid-19, has not previously been identified in the human body and is included in a new type of disease. Sars-CoV-2 (Kemenkes RI, 2020:11) is the cause of the Covid-19 virus from China, more precisely from the city of Wuhan. People infected with this virus usually experience symptoms such as shortness of breath, cough, fever, and visible pneumonia in the lungs on X-ray results. The incubation period is an average of 5 to 6 days, and the longest is 14 days. The heaviest cases of Covid-19 can cause sufferers to experience pneumonia, kidney failure, acute respiratory syndrome, and even death.

A person who has been infected with Covid-19 can easily transmit it to others through saliva dripping or from the nose when sneezing or coughing (WHO, 2020). The saliva droplets from the infected person mostly fall on the surrounding surfaces/objects such as tables or chairs or other objects. A person can be infected by touching an object that has been exposed to the virus and then touching his mouth, nose, and eyes before washing his hands (Permata \& Bhakti, 2020). Things that are trivial but have a vital impact, are often ignored, so that this epidemic quickly spread to several countries, including Indonesia. Indonesia first announced that one of its citizens was confirmed to have been exposed to COVID-19 in early March. Until now, 20 November 2020 (The COVID-19 Handling Task Force) Indonesia announced that the number of COVID-19 patients had reached 488,310 with 410,552 recovered patients.

The increasing number of COVID-19 patients has disrupted many sectors, one of them is the education sector. Various countries including Indonesia (Purwanto et al., 2020) have taken steps to temporarily stop all educational activities, this requires the government and related institutions to provide educational alternatives that must be taken for students who cannot carry out learning activities at the educational institution.

Based on press release number 137 by the Ministry of Education and Culture, as of July 2020, until a deadline that has not been determined, teachers and students are not allowed 
to conduct face-to-face learning as usual except in the green zone area. Areas with green (safe) zones are allowed to carry out face-to-face learning activities but still comply with health protocols following the "Guidelines for Implementation of Learning in the Covid-19 Pandemic" from the minister of education. While the orange, yellow and red zones are not allowed to carry out face-to-face learning. Learning in areas with these zones is shifted to BDR or Learning from Home (Kemendikbud, 2020a).

Learning from home means that learning activities are not carried out face-to-face in schools or other educational institutions. Both teachers and students carry out learning at home through print media such as textbooks, articles, or electronic media such as laptops, television, radio, or gadgets. As with one of the main principles of learning (Juwantara, 2019) that is active learning, students learn on their own by digging up information, conducting their experiments, and so on, which is a principle in helping to develop students' cognitive. This is following the current conditions during the COVID-19 pandemic.

Meanwhile, according to Nurdyansyah \& Fahyuni (2016) distance learning, or what is commonly referred to as distance learning is learning where students and teachers are not in the same place and time. According to Warsita (2014), three aspects of distance learning are teachers/educators with separate students (not in the same place), independence, and the existence of learning services.

Based on SE Number 15 of 2020 (Kemendikbud, 2020:2-3) concerning Guidelines for Organizing Learning from Home in an Emergency Period for the Spread of Corona Virus Disease (Covid-19) states that the distance learning approach that can be used during this pandemic is online (online learning) or offline (learning outside the network), it can also be a combination of online and offline. Each school institution can choose an approach that is following the readiness of its infrastructure. The media that can be used in the offline approach are radio, television, modules, printed teaching materials as well as teaching aids, and other media that come from the students' immediate environment. While the media used in the online approach are gadgets/ cellphones and laptops/computers through learning applications that are widely used online. Some applications that can be used are WhatsApp Groups, Zoom, Youtube, Google Meet, Google Forms, Google Classroom, etc.

As well as SD Alam which uses one of the default applications from Google, that is Google Classroom, to be a means for teachers and students in the implementation of distance learning. Some of the advantages of Google Classroom are the reasons for SD Alam using this application as a learning media, that are:

1. Teachers can deliver material in the form of files, images, videos, sound recordings, even links that can be directly directed to Youtube.

2. Teachers and students can also easily access it anywhere and anytime.

3. The submitted materials will not fill the memory card on the smartphone because all files (images/photos, sound recordings, videos) will be stored neatly on Google Drive, and can be downloaded and reopened at any time.

4. Teachers can provide direct assessments in Google Classroom and students can also view them.

5. Teachers and students can conduct online discussions.

6. Teachers can set deadlines for students to do assignments. This can make students disciplined.

7. There are notifications/reminders. This notification is a notification for students when there are new materials/assignments sent by the teacher, as well as a notification of the deadline for completing assignments.

8. Students can see the invoice for assignments that have not been done or sent and assignments that have been submitted. 
9. The application is Google Classroom also environmentally friendly (Putri et al., 2019), in collecting their assignments students do not use paper to make this application environmentally friendly.

\section{METHOD}

This research is qualitative research, which is an approach that emphasizes the analysis in the form of deductive and inductive conclusions, not research that emphasizes numerical data in its analysis (Azwar, 2001). The method used to collect data is in the form of interviews, observations, and documentation which is carried out via online (personal WhatsApp) and directly, in this case, students and parents of students are the main sources of data collection. While the data analysis techniques used are data reduction, data presentation, and conclusions. This research was conducted at SD Alam Ma'had Islam Pekalongan City with the research subjects being students and parents of 6th-grade referred students, while the object of research was related to the use of google classroom. This location was chosen because the researcher, who is also a teacher at the school, knows more about problems related to distance learning at SD Alam Ma'had Islam Pekalongan City. The benefits obtained from this research are that it can be used as evaluation material for schools in implementing online mode distance learning. In addition, it can be used as reference material in determining suitable learning media to be used in distance learning.

\section{RESEARCH RESULTS AND DISCUSSION}

The existence of COVID-19 has an impact on various aspects, including the aspect of education in Indonesia. Based on the SE Minister of Education and Culture Number 4 of 2020, regarding the Implementation of Education Policies in the Emergency Period for the Spread of Covid, in point 2. It is stated that learning activities are carried out online/remotely (Mendikbud, 2020). This is something new for the education world of Indonesia because the majority of people do not know yet about the distance learning system. In addition, the teacher did not have time to prepare everything needed for the implementation of this distance learning.

PJJ activities during the COVID-19 pandemic, of course, require media to help smooth learning activities. Google Classroom is an application that can be an alternative media in distance learning activities. In 2014-2016 google classroom was not intended for everyone, but only for schools that collaborated with Google, but in March 2017 this application began to be accessed by everyone using a personal google account. This of course can be a means for teachers, students, and parents to support learning activities without having to cooperate with Google (Wicaksono \& Rachmadyanti, 2016). 


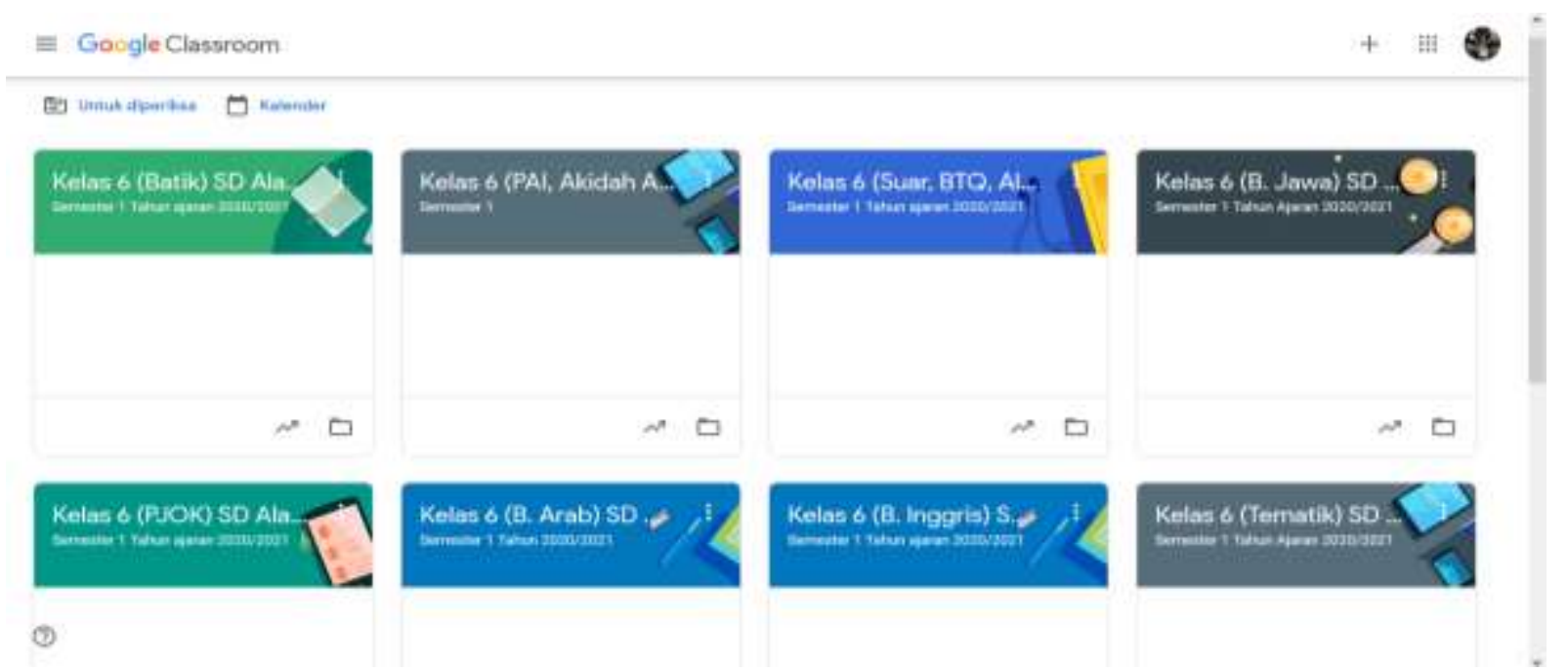

Picture 1. Google Classroom Display on Laptop/Computer Screen

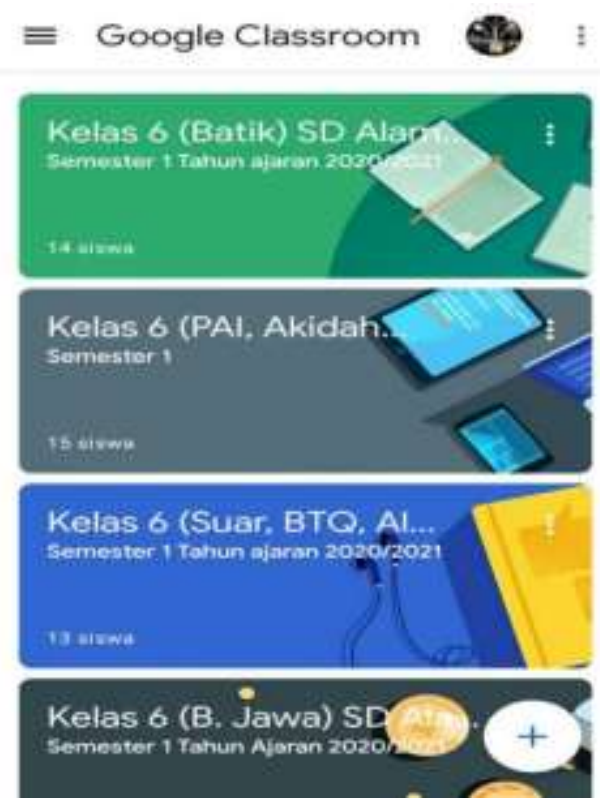

\section{Picture 2. Google Classroom Display on The Android Screen}

Not only in class, but this application can also be used outside the classroom. This means that this application can be used anywhere and anytime (Sukmawati \& Nensia, 2019). Conditions that do not allow face-to-face learning make this application an alternative for teachers and students to carry out learning activities with a remote system during the COVID19 pandemic.

Before its implementation, SD Alam Ma'had Islam provided socialization to parents of 6th-grade students to introduce the Google Classroom application which will be used as a learning tool during the COVID-19 pandemic. The socialization activity for the introduction of google classroom to parents of 6th-grade students was held on July 20, 2020. Parents of students practiced directly how to use it, starting from downloading the google classroom application, creating an email account to enter google classroom, joining classes (per subject), to send the tasks. In this socialization activity, many parents complained because they found it difficult to use it, especially for parents who were 'untechnical'. Some of them also complained that their gadgets had low storage capacity, so they could not download the Google Classroom application. Another complaint is that some parents ask for face-to-face learning to continue Al-Adzka: Vol. 11, No. 1, June 2021 
because they are worried that if they are transferred to PJJ (distance learning) the children will play games more often than study or do assignments.

After the socialization activity, parents teach their children (6-grade students) who already have their own gadgets about using Google Classroom, so they can send their assignments if at any time their parents cannot accompany them. Meanwhile, students who do not have gadgets on their own will be assisted by their parents for sending assignments.

Within one month of implementing Google Classroom, complaints started to be submitted by students' parents, either through personal WhatsApp, during home visits or meeting teachers directly at school. Several things parents complained about, including:

1. Both parents and students often find it difficult to open or send assignments in the form of photos or videos. This is due to a weak internet network. According to the parents' explanation, it's not enough to just rely on internet quota to open or send assignments, because even if there is a quota if the internet network is weak, it still takes a long time to open or send assignments, or even can't open and send them at all. One of the students' parents stated that he had to ride their gadget to a neighbor's wifi for his son's schoolwork.

2. The quota/ cellular data run out quickly due to the use of google classroom

Some applications do require quite a lot of quota/ cellular data for their use, including the google classroom application. The results of interviews with parents explained that they complained about the use of Google Classroom which often used up cellular data.

Tabel 1. Summary of Interview Results with Parents

\begin{tabular}{|c|c|}
\hline $\begin{array}{c}\text { Questions } \\
\end{array}$ & Answer \\
\hline \multicolumn{2}{|l|}{ Respondent 1 (Students parents) } \\
\hline $\begin{array}{l}\text { 1. How has distance learning been } \\
\text { implemented so far? }\end{array}$ & $\begin{array}{l}\text { - Thank God it went smoothly, although there } \\
\text { were some problems }\end{array}$ \\
\hline $\begin{array}{l}\text { 2. What media are used during distance } \\
\text { learning? }\end{array}$ & - Google classroom \\
\hline $\begin{array}{l}\text { 3. Is there any socialization activity for the } \\
\text { introduction of Google Classroom? If so, } \\
\text { can socialization help parents in using it? }\end{array}$ & $\begin{array}{l}\text { - There was, it was very helpful, at first I didn't } \\
\text { know about Google Classroom so finally found } \\
\text { out }\end{array}$ \\
\hline $\begin{array}{l}\text { 4. Were the teachers taught how to use google } \\
\text { classroom during the socialization } \\
\text { activities? }\end{array}$ & - Yes, we were taught how to use it \\
\hline $\begin{array}{l}\text { 5. How is distance learning implemented using } \\
\text { google classroom? }\end{array}$ & $\begin{array}{l}\text { - At first, I was confused about how to use it, but } \\
\text { eventually, I got used. }\end{array}$ \\
\hline $\begin{array}{l}\text { 6. According to parents, what are the } \\
\text { advantages of google classroom? }\end{array}$ & $\begin{array}{l}\text { - In my opinion, even though I download my } \\
\text { son's assignment in the form of videos, voice } \\
\text { recording, or photos, but it doesn't fill the } \\
\text { cellphone gallery. So, my cellphone memory } \\
\text { doesn't fill up quickly. }\end{array}$ \\
\hline $\begin{array}{l}\text { 7. Is there any problem with recording google } \\
\text { classroom? }\end{array}$ & $\begin{array}{l}\text { - The problem is signal, the signal must be strong } \\
\text { so I can open and send assignments in google } \\
\text { classroom }\end{array}$ \\
\hline 8. Suggestions for distance learning? & $\begin{array}{l}\text { - If you can just use WhatsApp because it's easier } \\
\text { and the signal doesn't have to be strong }\end{array}$ \\
\hline \multicolumn{2}{|l|}{ Respondent 2 (Students Parents) } \\
\hline $\begin{array}{l}\text { 1. How is distance learning implemented all } \\
\text { this time? }\end{array}$ & $\begin{array}{l}\text { - This distance learning makes me have to be } \\
\text { extra patient with very difficult children when } \\
\text { asked to study and do assignments. }\end{array}$ \\
\hline $\begin{array}{l}\text { 2. What media are used during distance } \\
\text { learning? }\end{array}$ & $\begin{array}{l}\text { - From school, I was asked to use google } \\
\text { classroom, and initially, I used google }\end{array}$ \\
\hline
\end{tabular}


3. Is there any socialization activity for the introduction of Google Classroom? If so, can socialization help parents in using it?

4. Were the teachers taught how to use google classroom during the socialization activities?

5. How is distance learning implemented using google classroom?

6. According to parents, what are the advantages of google classroom?

7. Is there any problem with using google classroom?

8. Suggestions for distance learning? classroom a few times, but now I use WhatsApp more often to send my child's assignments.

- Yes, At first it helped because when we were socialized, we were taught to use it, but when we got home we forgot how to send assignments.

- Yes, we were taught to use it in detail.

- It's good to use google classroom if the signal supports it, and if the quota assistance from the government continues, it's okay, because buy quota itself so lavishly once

- There are reminders such as alarms when the time limit is up to work on the assignment, so my son could discipline

- A long time when it will open google classroom, also hard to download and send the child's assignment.

- I wanted face-to-face because children will understand more about learning direct method rather than online, and so that they are not playing games all the time, but because it's still a pandemic it's also not possible to meet faceto-face. If this has to stay online, if it possible the assignment is sent via whatsapp because it is more economical to use whatsapp than google classroom

Respondent 3 (Students)

1. How has distance learning been implemented so far?

2. What media are used during distance learning?

3. Is there any socialization activity for the introduction of Google Classroom? If so, can socialization help students in using it?

4. How is distance learning implemented using google classroom?

5. According to students, what are the advantages of google classroom?

6. Is there any problem with using google classroom?

7. Suggestions for distance learning?
- During covid-19, I played more time, but my mother often scolded me if I didn't do my assignments

- Google classroom, but sometimes I used WhatsApp if it was difficult to open Google Classroom, sometimes I used Google Forms for tests, and I had video calls with ustadzah

- There was, but it was my mom who attended After socialization, I taught by my mom how to use google classroom

- Indifferent

- Duties are arranged by subject, there is a Complaints which complaints reminder

- Difficult signal. Sometimes I have to go to my neighbors to ride wifi and to send assignments

- Want to go to school, so I can meet friends and the lessons are better understood if explained directly by the ustadzah 


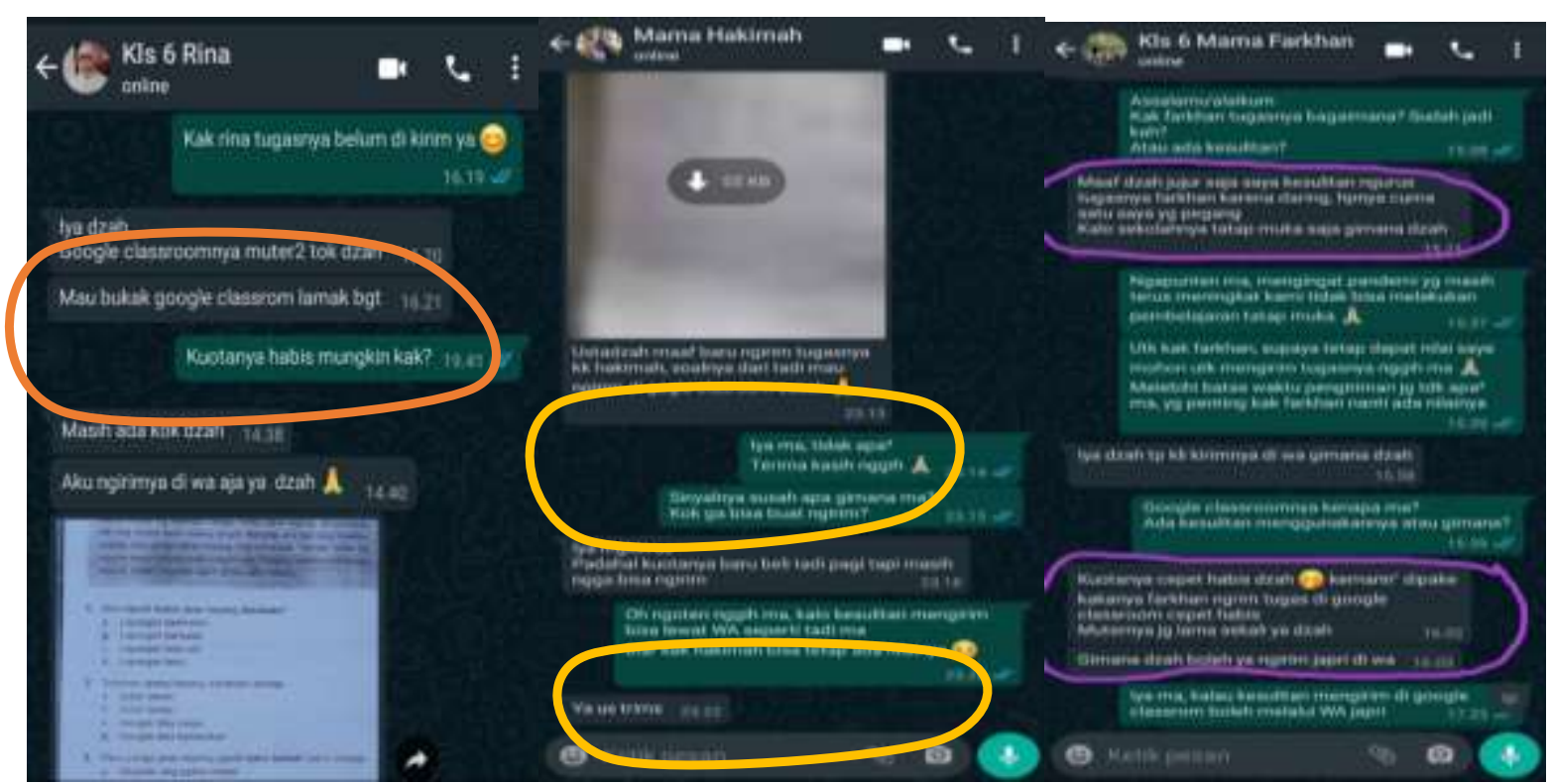

Picture 3. Assignments via WhatsApp and Complains from Parents and Students using Google Classroom

Both parents and students themselves often urge teachers to change distance learning activities from using Google Classroom to using WhatsApp groups. This opinion was conveyed by eight people (about 67\%) of the total number of class VI students, that are 12 children. Three of the eight people expressed their opinions and complains directly with the teacher at the school, three others through chat private with the class teacher, while the remaining two people expressed their opinions and complaints during home visits.

This opinion is certainly not without reason, they think that learning to use WhatsApp is easier to use because it is an application that is often used in their daily lives. In addition, it doesn't take long to be able to open assignments sent by the teacher or when they want to send assignments. In line with Agustini (2020), in her research, she stated that the reason for choosing WhatsApp as a learning media during the pandemic was its easy operation. In addition, there is a content group chat that can accommodate several members in one group. The existence of this group chat makes it easier for teachers to send assignments in the form of pictures, videos, files, and so on, during learning activities.

In addition to WhatsApp groups, teachers also use google forms and video calls from the WhatsApp application to overcome student boredom because they often study online. The teacher makes video calls to deliver the material or just to greet students. Meanwhile, to carry out daily assessments, the teacher uses a google form that can make it easier for students to take part in the assessment in conditions of the covid-19 pandemic. 


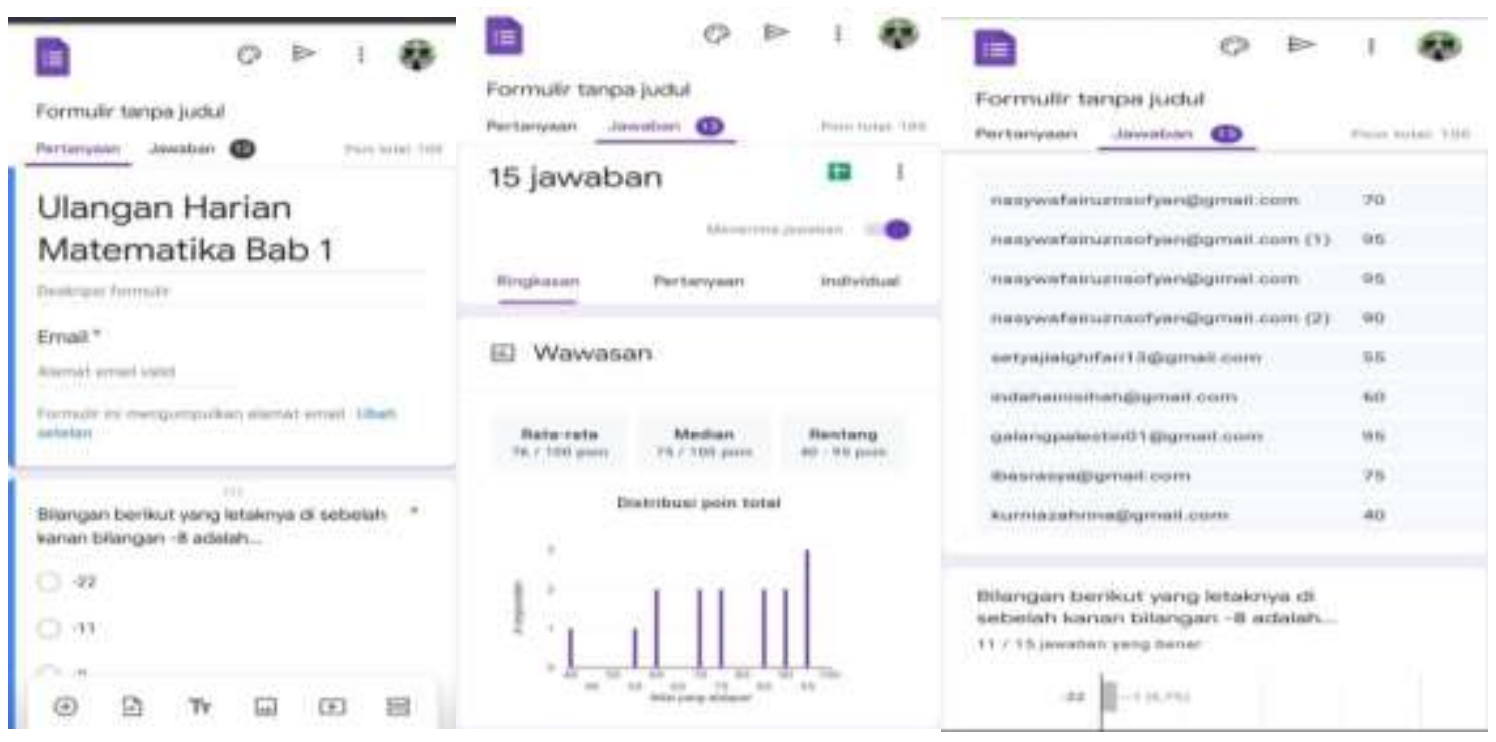

Picture 4. Daily Assessment Through Google Form

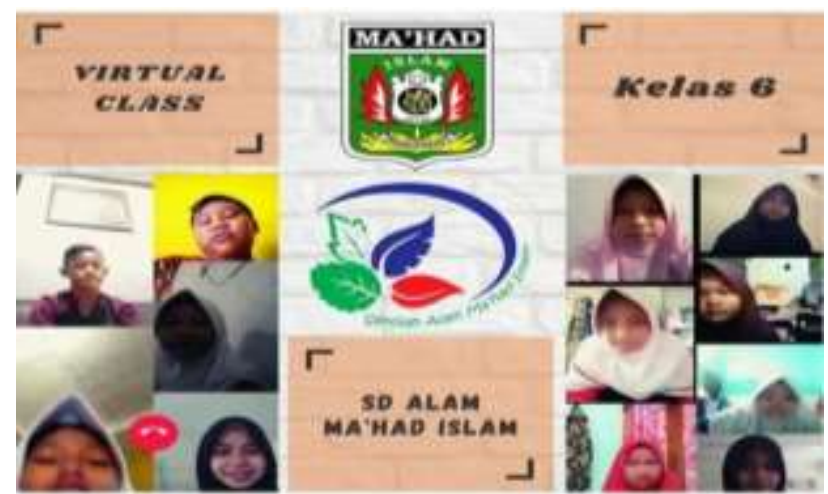

Picture 9. Video Call with Students

\section{CONCLUSION}

Response of parents and 6th-grade students in using the distance learning application Google Classroom, which was at the beginning of the introduction they found it difficult to use it because this application was an application that they just knew and knew about. Within a month of applying Google Classroom, various complaints emerged from students and parents. They find it difficult to open the bill of assignments from the teacher or when they want to send it. In addition, the data package used is also quickly used up for the use of this application. An alternative to overcome this is to send assignments via WhatsApp to the teacher concerned, for students and parents who have difficulty sending assignments via Google Classroom. In addition, teachers also use video calls as additional media in delivering learning materials, on several occasions, teachers also use google forms as a media for conducting daily assessments on students.

\section{REFERENCES}

Azwar, S. (2001). Metode Penelitian. Yogyakarta: Pustaka Pelajar.

Indrajit, Richardus Eko. (2016). E-Learning dan Sitem Informasi Pendidikan; Modul Pembelajaran Berbasis Standar Kompetensi dan Kualifikasi Kerja Edisi 2. Yogyakarta: Preinexus.

Nurdyansyah, \& Fahyuni, E. F. (2016). Inovasi Model Pembelajaran Sesuai Kurikulum 2013.

Sidoarjo: Nizamia Learning Center. 
Agustini, N. P. S. (2020). Penggunaan Media Sosial Whatsapp Pada Pembelajaran Agama Hindu Untuk Di Masa Pandemi. Jurnal Widya Sastra Pendidikan Agama Hindu, 3(1), 6772.

Juwantara, R. A. (2019). Analisis Teori Perkembangan Kognitif Piaget pada Tahap Anak Usia Operasional Konkret 7-12 Tahun dalam Pembelajaran Matematika. Al-Adzka: Jurnal Ilmiah Pendidikan Guru Madrasah Ibtidaiyah, 9(1), 27. https://doi.org/10.18592/aladzkapgmi.v9i1.3011

Kemendikbud. (2020a). Jika Satuan Pendidikan Sudah Memenuhi Semua Daftar Periksa Dan Siap Melakukan Pembelajaran Tatap Muka.

Kemendikbud. (2020b). Surat Edaran Jendral No. 15 Tahun 2020. 09, 1-12.

Kemenkes RI. (2020). Pedoman Pencegahan dan Pengendalian Coronavirus Disease (COVID19). Germas, 0-115.

Mendikbud. (2020). C. d. 0.0075 300. 300.

Permata, A., \& Bhakti, Y. B. (2020). Keefektifan Virtual Class dengan Google Classroom dalam Pembelajaran Fisika Dimasa Pandemi Covid-19. JIPFRI (Jurnal Inovasi Pendidikan Fisika dan Riset Ilmiah), 4(1), 27-33. https://doi.org/10.30599/jipfri.v4i1.669

Purwanto, A., Pramono, R., Asbari, M., Budi Santoso, P., Mayesti Wijayanti, L., Chi Hyun, C., \& Setyowati Putri, R. (2020). Universitas muhammadiyah enrekang. 2, 1-12.

Putri, G. K., Ani, Y., \& Dewi, S. (2019). Pengaruh Model Pembelajaran Jarak Jauh Berbasis Google Classroom Effect Of Google Classroom-Based Distance Learning Model. AlFikrah, 2(1), 60-79.

Sukmawati; \& Nensia. (2019). The Role of Google Classroom in ELT. International Journal for Educational and Vocational Studies, 1(2), 142-145. https://doi.org/10.29103/ijevs.v1i2.1526

Warsita, B. (2014). THE PATTERNS OF LEARNING ACTIVITIES IN DISTANCE. 73-83.

Wicaksono, V. D., \& Rachmadyanti, P. (2016). Pembelajaran Blended Learning melalui Google Classroom di Sekolah Dasar. Seminar Nasional Pendidikan PGSD UMS \& HDPGSDI Wilayah Timur, 513-521. http://hdl.handle.net/11617/9144

Google. (2020). About Classroom. Retrieved 12 02, 2020, from https://support.google.com/edu/classroom/answer/6376881?hl=en

Satgas Penanganan COVID-19. (n.d.). Retrieved November 20, 2020, from https://covid19.go.id/

WHO. (2020). World Health Organization. Retrieved from https://www.who.int/healthtopics/coronavirus\#tab=tab_1 